\title{
Nitrogen Dynamics Variation in Overlying Water of Jinshan Lake, China
}

\author{
Xiaohong Zhou, Mingyuan Wang, Longmei Liu, \\ Zhigang Chen, Yimin Li, and Jinping Zhang \\ School of the Environment and Safety Engineering, Jiangsu University, Zhenjiang 212013, China \\ Correspondence should be addressed to Xiaohong Zhou; xhzhou0214@163.com
}

Received 12 December 2014; Revised 2 February 2015; Accepted 2 February 2015

Academic Editor: Jian Lu

Copyright (c) 2015 Xiaohong Zhou et al. This is an open access article distributed under the Creative Commons Attribution License, which permits unrestricted use, distribution, and reproduction in any medium, provided the original work is properly cited.

Jinshan Lake is a famous urban landscape lake with approximately $8.8 \mathrm{~km}^{2}$ water area, which is located on the north of Zhenjiang, of Jiangsu Province, China. Eighteen sampled sites were selected and overlying water was sampled from 2013 to 2014 to study the seasonal and spatial variation of nitrogen in overlying water of Jinshan Lake. Results showed that physicochemical characteristics of temperature, $\mathrm{pH}$, and $\mathrm{DO}$ showed high seasonal variation, whereas they had no significant spatial differences in the 18 sampling points $(P>0.05)$ in overlying water of Jinshan Lake. Nitrogen concentrations showed strong seasonal variation trends. The ranked order of TN was as follows: spring $>$ summer $>$ autumn $>$ winter; the order of $\mathrm{NH}_{4}{ }^{+}-\mathrm{N}$ was as follows: spring $>$ autumn $>$ summer $>$ winter, whereas $\mathrm{NO}_{3}{ }^{-}-\mathrm{N}$ concentrations revealed an inverse seasonal pattern, with maxima occurring in winter and minimal values occurring in spring. Nitrogen concentrations had dramatic spatial changes in 18 sampling points of Jinshan Lake. Physicochemical parameter difference, domestic wastes pollution, and rainfall runoff source may have led to seasonal and spatial fluctuation variations of nitrogen in overlying water of Jinshan Lake, China.

\section{Introduction}

With the rapid development of economy and urbanization in recent years, excessive pollutants had been increasingly produced and discharged into rivers and lakes owing to human influences, resulting in severe degradation of water quality and a growing pressure on the local environment and restricting of the sustainable development of the local economies $[1,2]$. As a result, a lot of lakes, such as Lake Taihu $[3,4]$, Chao Lake [5], and Dianchi Lake [6], had been seriously polluted, and their water quality changed from clean to eutrophication [7], which seriously affects the lake ecological functions as a service of drinking water supply, flood control, tourism and recreation, shipping, and aquaculture $[1,4]$. Therefore, the lake water quality purification is an important objective for administrators of water environments in various cities in China.

Jinshan Lake is a famous urban landscape lake, which is located on the north of Zhenjiang District with $4 \mathrm{~km}$ length and $2 \mathrm{~km}$ width and water area is $8.8 \mathrm{~km}^{2}$ [8]. At present, there are some pollution water, such as urban domestic sewage, urban surface runoff and pollution river, had discharged into Jinshan Lake, which lead to a deterioration of water quality in Jinshan Lake, especially nitrogen. It is necessary to study the nitrogen concentration in overlying water of Jinshan Lake, China. Therefore, the goal of this study was to monitor seasonal and spatial variation of nitrogen in overlying water of Jinshan Lake in a one-year period, and the results of this study will provide an important basis character for Jinshan Lake pollution control.

\section{Materials and Methods}

2.1. Study Region and Study Sites. The study region in this study is located on Jinshan Lake, Zhenjiang, Jiangsu Province, China $\left(32^{\circ} 13^{\prime} 4.65^{\prime \prime}-32^{\circ} 14^{\prime} 35.79^{\prime \prime} \mathrm{N}, 119^{\circ} 25^{\prime} 5.71^{\prime \prime}-\right.$ $\left.119^{\circ} 29^{\prime} 48.05^{\prime \prime} \mathrm{E}\right)$. This region is characterized by the north subtropical monsoon climate, with mean annual temperature and rainfall of $15.6^{\circ} \mathrm{C}$ and $1088.2 \mathrm{~mm}$, respectively.

Jinshan Lake is located on the north of Zhenjiang District. It is about $4 \mathrm{~km}$ in length and $2 \mathrm{~km}$ in width and is a shallow 
TABLE 1: Summary statistics of mean nitrogen concentrations in overlying water of Jinshan Lake.

\begin{tabular}{lcccccc}
\hline Item & \multicolumn{3}{c}{ Nitrogen concentrations $\left(\mathrm{mg} \cdot \mathrm{L}^{-1}\right)$} & & \multicolumn{2}{c}{ Percentage (\%) } \\
& $\mathrm{TN}$ & $\mathrm{NH}_{4}{ }^{+}-\mathrm{N}$ & $\mathrm{NO}_{3}{ }^{-}-\mathrm{N}$ & $\mathrm{NH}_{4}{ }^{+}-\mathrm{N}$ & $\mathrm{NO}_{3}{ }^{-}-\mathrm{N}^{2}$ & $\mathrm{NH}_{4}{ }^{+}-\mathrm{N}^{-} \mathrm{NO}_{3}{ }^{-}-\mathrm{N}^{-}$ \\
\hline Average & 3.55 & 0.23 & 0.41 & 6.78 & 11.73 & 18.51 \\
Minimum & 2.13 & 0.16 & 0.33 & 4.32 & 8.45 & 14.80 \\
Maximum & 4.54 & 0.39 & 0.50 & 13.64 & 15.69 & 26.56 \\
S.D. & 0.65 & 0.06 & 0.05 & 2.62 & 1.96 & 3.79 \\
CV (\%) & 18.34 & 27.68 & 11.95 & 38.63 & 16.71 & 20.47 \\
\hline
\end{tabular}

S.D.: standard deviation; CV: coefficients of variation.

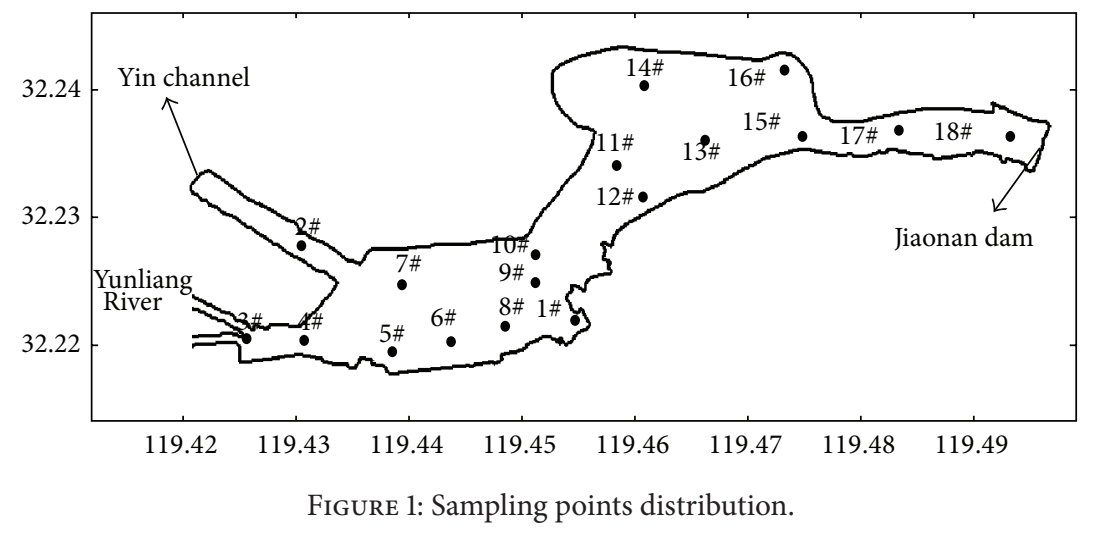

lake with 2-6 m water depth. The total water area is $8.8 \mathrm{~km}^{2}$. It is the largest lake, accounting for more than $80 \%$ of surface water of Zhenjiang District. Yin channel and Jiaonan dam control the influent and effluent of Jinshan Lake, respectively. Water source of Jinshan Lake is mainly from Yangtze River supply. Its primary pollution sources include urban domestic sewage, urban surface runoff, atmospheric dry deposition, river pollution, and anthropogenic activities such as water sports entertainment. In this study, all 18 points were selected as monitoring sites and each sampling site is listed in Figure 1.

2.2. Sampling Collection and Physicochemical Characteristics Analysis. Eighteen water samples were collected at about 25$30 \mathrm{~cm}$ water depth at each study site using a water collector for analysis of physicochemical characteristics on October 13 of 2013 (autumn) and January 10 (winter), April 15 (spring), and July 5 of 2014 (summer), respectively.

Ammonia $\left(\mathrm{NH}_{4}{ }^{+}-\mathrm{N}\right)$, nitrate $\left(\mathrm{NO}_{3}{ }^{-}-\mathrm{N}\right)$, and total nitrogen (TN) were determined according to the protocols described in Chinese Standard Methods (Editorial Board of Monitoring and Analytical Method of Water and Wastewater, 2002). Temperature, $\mathrm{pH}$, and dissolved oxygen (DO) of each sample site were also monitored in situ. $\mathrm{pH}$ was measured using HI 98128 pH meter (Hanna Co., Italy). DO and temperature were measured using HQ30d Dissolved Oxygen Instrument (HACH, USA).

2.3. Calculations and Statistics. Data was calculated by using Microsoft Office Excel. Statistical analyses were performed using SPSS 19.0. One-way ANOVA was performed to determine significant differences in seasonal and spatial variation of nitrogen. Linear regression analysis was used to determine the relationship between nitrogen content and environmental factors.

\section{Results}

3.1. Physicochemical Characteristics in Overlying Water of Jinshan Lake. The temperature showed a high seasonal variation trend from a minimum of $5.9^{\circ} \mathrm{C}$ in January to a maximum of $27.2^{\circ} \mathrm{C}$ in July and its average values were $22.76,6.42,19.16$, and $26.81^{\circ} \mathrm{C}$ in autumn, winter, spring, and summer, respectively (Figure 2(a)). Water chemistry also showed large variations in overlying water of Jinshan Lake. The DO varied seasonally, with the peaks in winter and lowest value in July and its average values were $8.17,13.21,9.70$, and 8.70 in autumn, winter, spring, and summer, respectively (Figure $2(\mathrm{~b})$ ). The $\mathrm{pH}$ ranged from 7.2 in October to 9.03 in July, with average values of $7.76,8.68,8.57$, and 8.63 in autumn, winter, spring, and summer, respectively, which also revealed a seasonal variation pattern (Figure 2(c)). Statistics results showed that there had been significant differences of $\mathrm{pH}$, temperature, and $\mathrm{DO}$ among the four seasons $(P<0.05)$.

The highest values of $\mathrm{DO}$ and $\mathrm{pH}$ occurred in 11\# and 12\# sites, whereas the lowest values of $\mathrm{DO}$ and $\mathrm{pH}$ were obtained in $3 \#$ and $1 \#$ sites. Statistics results showed that there had been no significant differences of $\mathrm{pH}$, temperature, and $\mathrm{DO}$ between the 18 sampling points $(P>0.05)$.

3.2. Mean Nitrogen Concentrations in Overlying Water of Jinshan Lake. Mean concentrations of nitrogen in overlying water of Jinshan Lake were summarized in Table 1. Results showed that the mean concentrations of $\mathrm{TN}, \mathrm{NH}_{4}{ }^{+}-\mathrm{N}$, and 


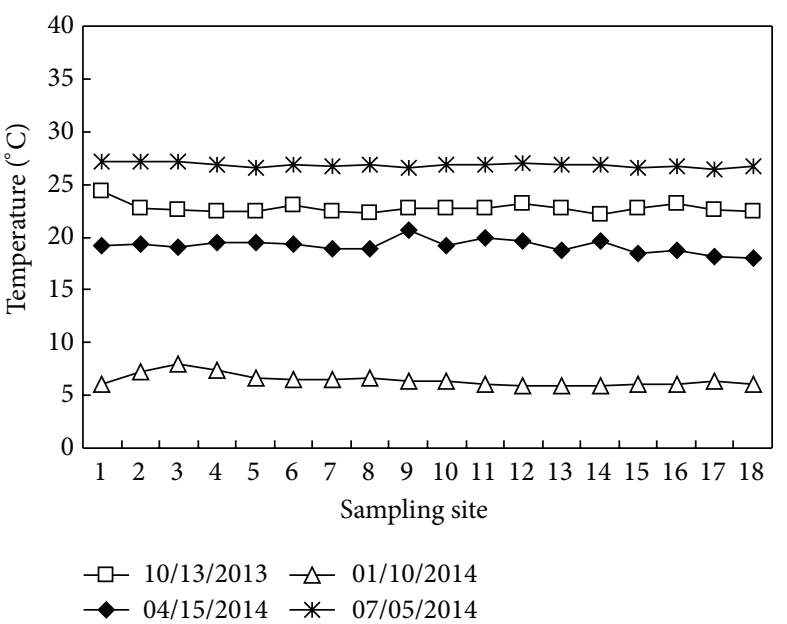

(a)

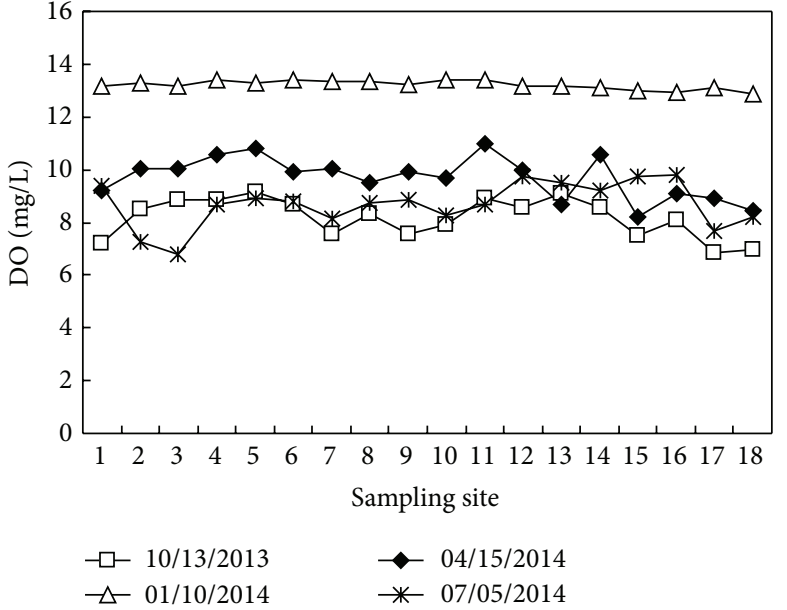

(b)

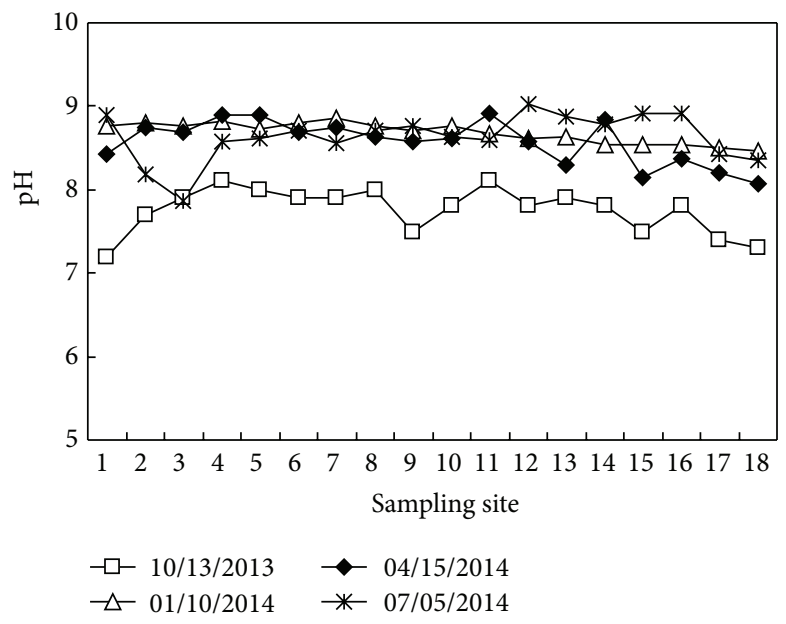

(c)

FIGURE 2: Variations of physicochemical characteristics in overlying water of Jinshan Lake.

$\mathrm{NO}_{3}{ }^{-}-\mathrm{N}$ were $3.55,0.23$, and $0.41 \mathrm{mg} \cdot \mathrm{L}^{-1}$, respectively. Compared with surface water quality standards [9], TN is generally inferior to Grade $\mathrm{V}$ water quality standards and $\mathrm{NH}_{4}{ }^{+}-\mathrm{N}$ is below Grade 4 water quality standards, which indicated that high concentrations of total nitrogen were the primary water quality problems in Jinshan Lake. The proportions of $\mathrm{NH}_{4}{ }^{+}-$ $\mathrm{N}$ were lower than those of $\mathrm{NO}_{3}{ }^{-}-\mathrm{N}$ in the water of Jinshan Lake.

3.3. Seasonal Variations of Nitrogen in Overlying Water of Jinshan Lake. Nitrogen concentrations showed strong seasonal variation trends (Figure 3). The TN concentrations ranged from 1.03 to $3.48 \mathrm{mg} \cdot \mathrm{L}^{-1}$, from 0.40 to $4.09 \mathrm{mg} \cdot \mathrm{L}^{-1}$, from 4.91 to $11.17 \mathrm{mg} \cdot \mathrm{L}^{-1}$, and from 0.48 to $5.03 \mathrm{mg} \cdot \mathrm{L}^{-1}$, with average values of $2.15,1.55,8.16$, and $2.35 \mathrm{mg} \cdot \mathrm{L}^{-1}$ in the autumn, winter, spring, and summer, respectively. TN concentrations had a maximum coefficients of variation $(\mathrm{CV})$ value in winter, reaching $62.65 \%$, followed by summer and its value was $60.31 \%$, which indicated the TN in winter and summer had large differences in each sampling point. In addition, maximum values of $\mathrm{TN}$ occurred in spring, whereas minimum values were confined to winter. The ranked order of mean concentration of TN was as follows: spring $>$ summer $>$ autumn $>$ winter.

The $\mathrm{NH}_{4}{ }^{+}-\mathrm{N}$ concentrations ranged from 0.18 to $0.54 \mathrm{mg} \cdot \mathrm{L}^{-1}$, from 0.05 to $0.19 \mathrm{mg} \cdot \mathrm{L}^{-1}$, from 0.26 to $0.75 \mathrm{mg} \cdot \mathrm{L}^{-1}$, and from 0.06 to $0.29 \mathrm{mg} \cdot \mathrm{L}^{-1}$, with average values of $0.25,0.10,0.42$, and $0.15 \mathrm{mg} \cdot \mathrm{L}^{-1}$ in the autumn, winter, spring, and summer, respectively. There was a maximum $\mathrm{CV}$ value of $\mathrm{NH}_{4}{ }^{+}-\mathrm{N}$ in summer (49.90\%), followed by autumn (38.83\%) and spring (36.73\%), respectively, and there was a minimum value the in the winter, which indicated the $\mathrm{NH}_{4}{ }^{+}-$ $\mathrm{N}$ had a large difference in summer, whereas it had a little difference in winter in each sampling point. Similar to the TN, average concentration of $\mathrm{NH}_{4}{ }^{+}-\mathrm{N}$ also reached a maximum value in the spring, while it had a minimum value in the winter. The ranked order of average concentration of $\mathrm{NH}_{4}{ }^{+}-\mathrm{N}$ was as follows: spring $>$ autumn $>$ summer $>$ winter. 


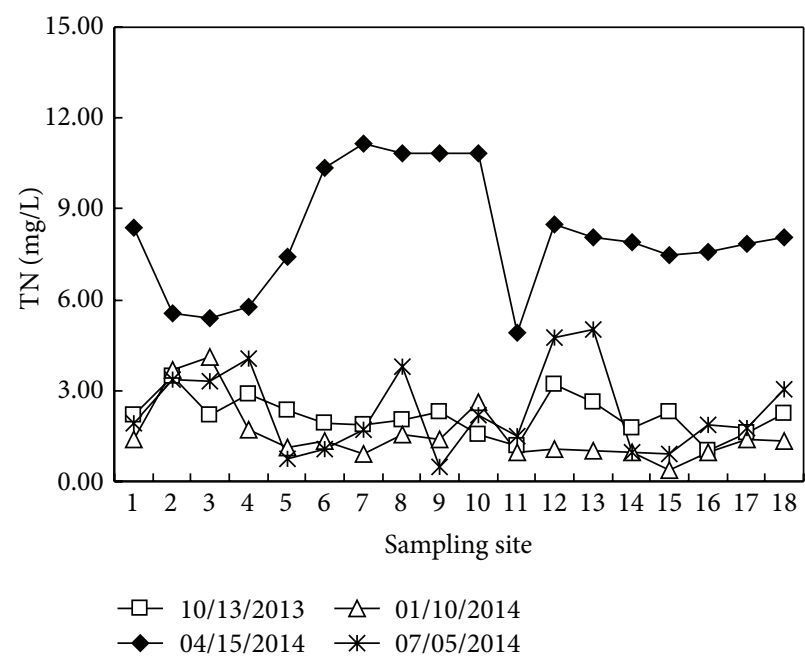

(a)

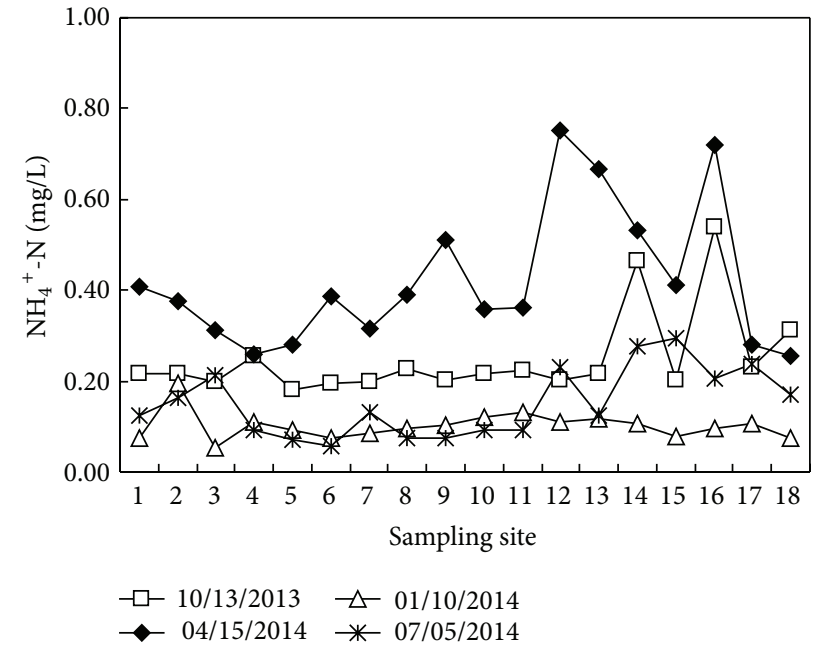

(b)

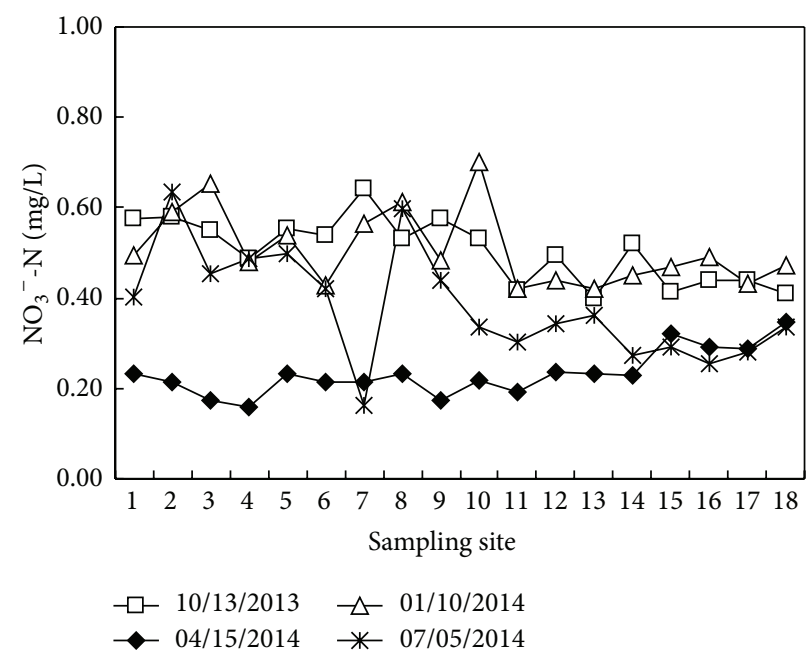

(c)

FIGURE 3: Variations of nitrogen in overlying water of Jinshan Lake.

The $\mathrm{NO}_{3}{ }^{-}-\mathrm{N}$ concentrations changed from 0.40 to $0.64 \mathrm{mg} \cdot \mathrm{L}^{-1}$, from 0.42 to $0.70 \mathrm{mg} \cdot \mathrm{L}^{-1}$, from 0.16 to $0.35 \mathrm{mg} \cdot \mathrm{L}^{-1}$, and from 0.16 to $0.63 \mathrm{mg} \cdot \mathrm{L}^{-1}$. Unlike the TN and $\mathrm{NH}_{4}{ }^{+}-\mathrm{N}, \mathrm{NO}_{3}{ }^{-}-\mathrm{N}$ concentrations revealed an inverse seasonal pattern, with maxima occurring in winter and minimal values occurring in spring. The maximum $\mathrm{CV}$ value of $\mathrm{NO}_{3}{ }^{-}$$\mathrm{N}$ was in summer $(31.88 \%)$, followed by spring $(21.61 \%)$ and winter $(16.71 \%)$, respectively, and it was a minimum value in the autumn (14.21\%), which indicated the $\mathrm{NO}_{3}{ }^{-}-\mathrm{N}$ had a large difference in summer, whereas it had a little difference in autumn in each sampling point.

\subsection{Spatial Variation of Nitrogen in Overlying Water of Jinshan} Lake. Spatial distribution patterns of nitrogen and summary statistics of each sampling site in overlying water of Jinshan Lake were also shown in Figure 3. Results showed that TN concentrations showed strong spatial variation trends. The highest values of TN concentrations occurred in 2\#, 3\#, 7\#, and $13 \#$ sites, reaching $3.48,4.09,11.17$, and $5.03 \mathrm{mg} / \mathrm{L}$ in autumn, winter, spring, and summer, respectively, whereas the lowest values were obtained in 16\#, 15\#, 11\#, and 9\# sites, reaching $1.03,0.40,4.90$, and $0.48 \mathrm{mg} / \mathrm{L}$ in autumn, winter, spring, and summer, respectively.

Similar to the $\mathrm{TN}, \mathrm{NH}_{4}{ }^{+}-\mathrm{N}$ concentrations also showed strong spatial variation trends. The highest values of $\mathrm{NH}_{4}{ }^{+}-$ $\mathrm{N}$ concentrations occurred in 16\#, 2\#, 12\#, and 15\# sites, reaching $0.54,0.19,0.75$, and $0.29 \mathrm{mg} / \mathrm{L}$ in autumn, winter, spring, and summer, respectively, whereas the lowest values were obtained in 5\#, 3\#, 18\#, and 6\# sites, reaching $0.18,0.05$, 0.26 , and $0.06 \mathrm{mg} / \mathrm{L}$ in autumn, winter, spring, and summer, respectively. Therefore, the highest values were 3.00, 3.60, 2.93, and 5.10 times compared to the lowest values in autumn, winter, spring, and summer, respectively, in overlying water of Jinshan Lake.

For $\mathrm{NO}_{3}{ }^{-}-\mathrm{N}$, the highest values occurred in 7\#, 10\#, 18\#, and $2 \#$ sites, reaching $0.64,0.70,0.35$, and $0.63 \mathrm{mg} / \mathrm{L}$ in autumn, winter, spring, and summer, respectively, whereas 
the lowest values were obtained in 13\#, 13\#, 4\#, and 7\# sites, reaching $0.40,0.42,0.16$, and $0.16 \mathrm{mg} / \mathrm{L}$ in autumn, winter, spring, and summer, respectively.

\section{Discussion}

$\mathrm{N}$ is mainly responsible for eutrophication and is considered to be the limiting element of primary productivity in most freshwater ecosystems $[10,11]$. Therefore, nitrogen is the control target for the restoration of water ecosystems $[12,13]$. Nitrogen cycle in the freshwater ecosystems relies on numerous factors, including water physicochemical quality $(\mathrm{pH}$, DO, temperature, etc.) and biological factors (aquatic plant, algae, and microorganisms). In this study, direct nitrogen uptake from overlying water could be neglected owing to the lack of macrophyte and phytoplankton growth in Jinshan Lake. Therefore, the nitrification-denitrification is the major process of nitrogen cycle.

Previous research indicated that DO plays an important role in nitrification-denitrification process. Nitrification is strictly aerobic (DO $>2.0 \mathrm{mg} / \mathrm{L}$ ), whereas denitrification is strictly anoxic $(\mathrm{DO}<1.0 \mathrm{mg} / \mathrm{L})$ [14-17]. In the present study, DO had concentrations of more than $2 \mathrm{mg} / \mathrm{L}$ in all sample sites in the four seasons. Except for spring, there was not a significant correlation between $\mathrm{N}$ concentrations and dissolved oxygen concentrations, which indicated that nitrification might not be caused by oxygen concentrations in overlying water of Jinshan Lake. However, under aerobic conditions, denitrification was limited by DO concentrations, which led to higher $\mathrm{NO}_{3}{ }^{-}$than $\mathrm{NH}_{4}{ }^{+}$in overlying water of Jinshan Lake. Besides, nitrification denitrification is also greatly dependent on $\mathrm{pH}$. Lu et al. [18] pointed out that typical nitrification processes have optimum $\mathrm{pH}$ values of 7.0-8.6. Prinčič et al. [19] showed that the optimal $\mathrm{pH}$ for nitrification is between 6.5 and 8.5. In this present study, there is an alkaline environment in Jinshan Lake and $\mathrm{pH}$ value changes from 7.2 to $8.1,8.46$ to $8.85,8.07$ to 8.92 , and 7.87 to 9.03 , in autumn, winter, spring, and summer, respectively. Significant positive correlation in winter and significant negative correlation in spring were found between $\mathrm{NO}_{3}{ }^{-}-\mathrm{N}$ and $\mathrm{pH}$ values in Jinshan Lake. These correlations may indicate that $\mathrm{pH}$ affected the nitrification-denitrification process to a certain degree. Furthermore, temperature is a key parameter to effecting nitrification-denitrification process [20, 21]. Picard et al. [22] showed that biological processes drastically slow down or cease with temperatures under "biological zero" or $5^{\circ} \mathrm{C}$. In this present study, the mean temperatures were $22.8,6.4$, 19.2 , and $26.8^{\circ} \mathrm{C}$, in autumn, winter, spring, and summer, respectively. Significant correlation in winter and spring was found between $\mathrm{NO}_{3}{ }^{-}-\mathrm{N}$ and water temperature in Jinshan Lake. These correlations indicate that water temperature was also an important factor and might be explained by the fact that the highest $\mathrm{NO}_{3}{ }^{-}-\mathrm{N}$ concentration was in winter and lowest $\mathrm{NO}_{3}{ }^{-}-\mathrm{N}$ concentration was in spring. Overall, $\mathrm{N}$ concentrations in overlying water of Jinshan Lake showed obvious seasonal changes in this study. These results were consistent with the findings of previous studies by Zhang et al. 2008 [5], Berman et al. 1984 [23], and Gu et al. 1997 [24].
In this research, the nitrogen concentrations also showed strong spatial variation difference. Now, industry pollution had been controlled to a certain degree in Jinshan Lake. Therefore, domestic wastes might be one of the main point sources in Jinshan Lake. There are several overflow ports from sewage pumping station and combined sewage pipeline in Lakeshore near 3\#-6\# and 8\# sites. For example, 3\# site was located on Yunliang River estuary and this river received $80 \%$ sewage wastes from 137.9 thousand coastal residents by overflow ports. 8 \# site was located on the Jiefang Road sewage pumping station. Secondly, rainfall runoff is also main source in Jinshan Lake. He [25] calculated the quantities of contaminations in Jinshan Lake from the main pollution sources and found that a total of $145.3 \mathrm{t} / \mathrm{a}$ of TN was discharged through surface runoff into Jinshan Lake, which contributed $62 \%$ TN in all pollution sources. Thirdly, atmospheric deposition, including dry deposition and wet deposition, contributed $16 \% \mathrm{TN}$ in all pollution sources and about $37.6 \mathrm{t} / \mathrm{a}$ of $\mathrm{TN}$ was conveyed into Jinshan Lake [25]. Based on the above multiple reasons, the highest values of TN concentrations occurred in $2 \#, 3 \#, 7 \#$, and $13 \#$ sites in autumn, winter, spring, and summer, respectively. However, the spatial sites of the $\mathrm{NH}_{4}{ }^{+}$$\mathrm{N}$ and $\mathrm{NO}_{3}{ }^{-}-\mathrm{N}$ highest concentrations were inconsistent with TN. These differences in spatial distribution were closely correlated with the physicochemical conditions differences in each site; other factors, such as pollution source, hydrodynamic force, and water entertainment activity, could also affect the spatial variation of nitrogen in overlying water of Jinshan Lake.

This study only investigated the variation of seasonal and spatial distribution in Jinshan Lake using just one-year monitoring data. More research needs to be carried out to reveal conversion mechanism between nitrogen forms to longer timescales in Jinshan Lake in further studies.

\section{Conclusions}

In summary, physicochemical characteristics and nitrogen in overlying water of Jinshan Lake showed clear seasonal variation. The highest values of $\mathrm{TN}$ and $\mathrm{NH}_{4}{ }^{+}-\mathrm{N}$ occurred in spring and the lowest values were obtained in winter, whereas $\mathrm{NO}_{3}{ }^{-}-\mathrm{N}$ revealed a different seasonal pattern, with maxima occurring in winter, respectively, and minimum values occurring in spring. Nitrogen concentrations reflected strong spatial variation in 18 sampling points in overlying water of Jinshan Lake. The seasonal and spatial variations of nitrogen indicated that nitrogen changes were related to internal physicochemical characteristics changes of overlying water and external contamination induced by human activity.

\section{Conflict of Interests}

The authors declare that there is no conflict of interests regarding the publication of this paper.

\section{Acknowledgments}

This work was supported by the National Natural Science Foundation of China (51109097), by the Jiangsu Province 
Basic Research Program (Natural Science Foundation funded project) (BK2011520), and by the China Postdoctoral Science Foundation funded project (2012T50464). The authors would like to acknowledge the financial support.

\section{References}

[1] H. Xu, L. Z. Yang, G. M. Zhao, J. G. Jiao, S. X. Yin, and Z. P. Liu, "Anthropogenic impact on surface water quality in Taihu Lake region, China," Pedosphere, vol. 19, no. 6, pp. 765-778, 2009.

[2] R. G. Li, Y. L. Xia, A. Z. Wu, and Y. S. Qian, "Pollutants sources and their discharging amount in Taihu Lake area of Jiangsu province," Journal of Lake Science, vol. 12, pp. 147-153, 2000 (Chinese).

[3] H. Xu, H. W. Paerl, B. Qin, G. Zhu, and G. Gao, "Nitrogen and phosphorus inputs control phytoplankton growth in eutrophic Lake Taihu, China," Limnology and Oceanography, vol. 55, no. 1, pp. 420-432, 2010.

[4] B. Q. Qin, P. Z. Xu, Q. L. Wu, L. C. Luo, and Y. L. Zhang, "Environmental issues of Lake Taihu, China," Hydrobiologia, vol. 581, no. 1, pp. 3-14, 2007.

[5] M. Zhang, J. Xu, and P. Xie, "Nitrogen dynamics in large shallow eutrophic Lake Chaohu, China," Environmental Geology, vol. 55, no. 1, pp. 1-8, 2008.

[6] J.-N. Chen, T.-Z. Zhang, and P.-F. Du, "Assessment of water pollution control strategies: a case study for the Dianchi Lake," Journal of Environmental Sciences, vol. 14, no. 1, pp. 76-78, 2002.

[7] W. Liu and R. Qiu, "Water eutrophication in China and the combating strategies," Journal of Chemical Technology and Biotechnology, vol. 82, no. 9, pp. 781-786, 2007.

[8] B. Liu, Y. M. Li, J. P. Zhang, X. H. Zhou, and C. D. Wu, "Abundance and diversity of ammonia-oxidizing microorganisms in the sediments of Jinshan Lake," Current Microbiology, vol. 69, no. 5, pp. 751-758, 2014.

[9] State Environmental Protection Administration of the P.R. China (SEPA), Environmental Quality Standards for Surface Water (GB3838-2002), China Environmental Science Press, Beijing, China, 2002, (Chinese).

[10] J. J. Elser, M. E. S. Bracken, E. E. Cleland et al., "Global analysis of nitrogen and phosphorus limitation of primary producers in freshwater, marine and terrestrial ecosystems," Ecology Letters, vol. 10, no. 12, pp. 1135-1142, 2007.

[11] R. W. Howarth and R. Marino, "Nitrogen as the limiting nutrient for eutrophication in coastal marine ecosystems: evolving views over three decades," Limnology and Oceanography, vol. 51, part 2, no. 1, pp. 364-376, 2006.

[12] J. L. Garland, L. H. Levine, N. C. Yorio, and M. E. Hummerick, "Response of graywater recycling systems based on hydroponic plant growth to three classes of surfactants," Water Research, vol. 38, no. 8, pp. 1952-1962, 2004.

[13] V. H. Smith, G. D. Tilman, and J. C. Nekola, "Eutrophication: impacts of excess nutrient inputs on freshwater, marine, and terrestrial ecosystems," Environmental Pollution, vol. 100, no. 13, pp. 179-196, 1998.

[14] C. C. Tanner, R. H. Kadlec, M. M. Gibbs, J. P. S. Sukias, and M. L. Nguyen, "Nitrogen processing gradients in subsurface-flow treatment wetlands - Influence of wastewater characteristics," Ecological Engineering, vol. 18, no. 4, pp. 499-520, 2002.

[15] J. Wu, J. Zhang, W. Jia et al., "Impact of $\mathrm{COD} / \mathrm{N}$ ratio on nitrous oxide emission from microcosm wetlands and their performance in removing nitrogen from wastewater," Bioresource Technology, vol. 100, no. 12, pp. 2910-2917, 2009.
[16] G. Tallec, J. Garnier, G. Billen, and M. Gousailles, "Nitrous oxide emissions from denitrifying activated sludge of urban wastewater treatment plants, under anoxia and low oxygenation," Bioresource Technology, vol. 99, no. 7, pp. 2200-2209, 2008.

[17] S. B. K. Sekiranda and S. Kiwanuka, "A study of nutrient removal efficiency of Phragmites mauritianus in experimental reactors in Uganda," Hydrobiologia, vol. 364, pp. 83-91, 1997.

[18] S. Y. Lu, X. C. Jin, and G. Yu, "Nitrogen removal mechanism of constructed wetland," Acta Ecologica Sinica, no. 26, pp. 26702677, 2006.

[19] A. Prinčič, I. Mahne, F. Megušar, E. A. Paul, and J. M. Tiedje, "Effects of $\mathrm{pH}$ and oxygen and ammonium concentrations on the community structure of nitrifying bacteria from wastewater," Applied and Environmental Microbiology, vol. 64, no. 10, pp. 3584-3590, 1998.

[20] A. G. Werker, J. M. Dougherty, J. L. McHenry, and W. A. Van Loon, "Treatment variability for wetland wastewater treatment design in cold climates," Ecological Engineering, vol. 19, no. 1, pp. 1-11, 2002.

[21] P. Kuschk, A. Wießner, U. Kappelmeyer, E. Weißbrodt, M. Kästner, and U. Stottmeister, "Annual cycle of nitrogen removal by a pilot-scale subsurface horizontal flow in a constructed wetland under moderate climate," Water Research, vol. 37, no. 17, pp. 4236-4242, 2003.

[22] C. R. Picard, L. H. Fraser, and D. Steer, "The interacting effects of temperature and plant community type on nutrient removal in wetland microcosms," Bioresource Technology, vol. 96, no. 9, pp. 1039-1047, 2005.

[23] T. Berman, B. F. Sherr, E. Sherr, D. Wynne, and J. J. McCarthy, "The characteristics of ammonium and nitrate uptake by phytoplankton in Lake Kinneret," Limnology \& Oceanography, vol. 29, no. 2, pp. 287-297, 1984.

[24] B. H. Gu, K. E. Havens, C. L. Schelske, and B. H. Rosen, "Uptake of dissolved nitrogen by phytoplankton in a eutrophic subtropical lake," Journal of Plankton Research, vol. 19, no. 6, pp. 759-770, 1997.

[25] M. He, Study on the water quality trend of dammed water bodya case of Jinshan Lake in Zhenjiang [Master dissertation], Jiangsu University, 2012. 

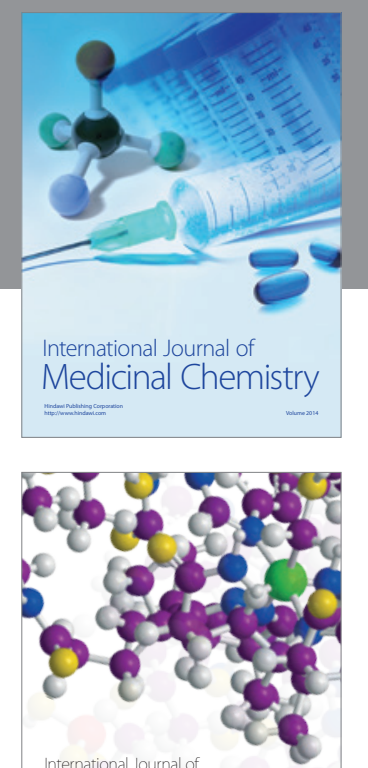

\section{Carbohydrate} Chemistry

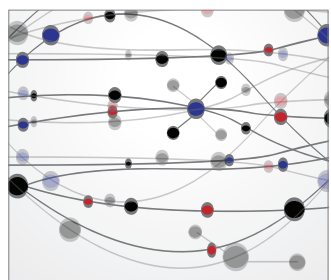

The Scientific World Journal
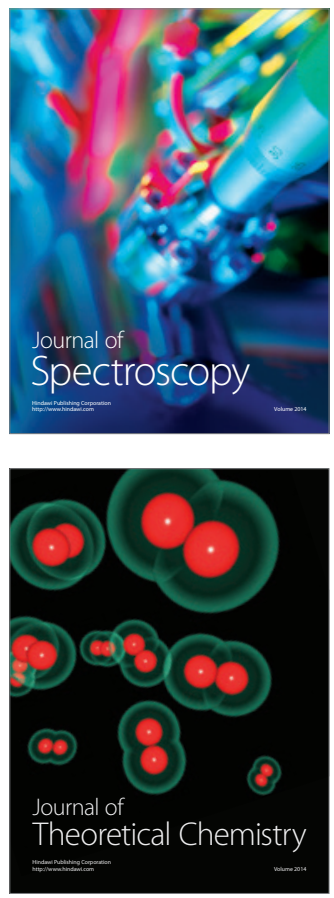
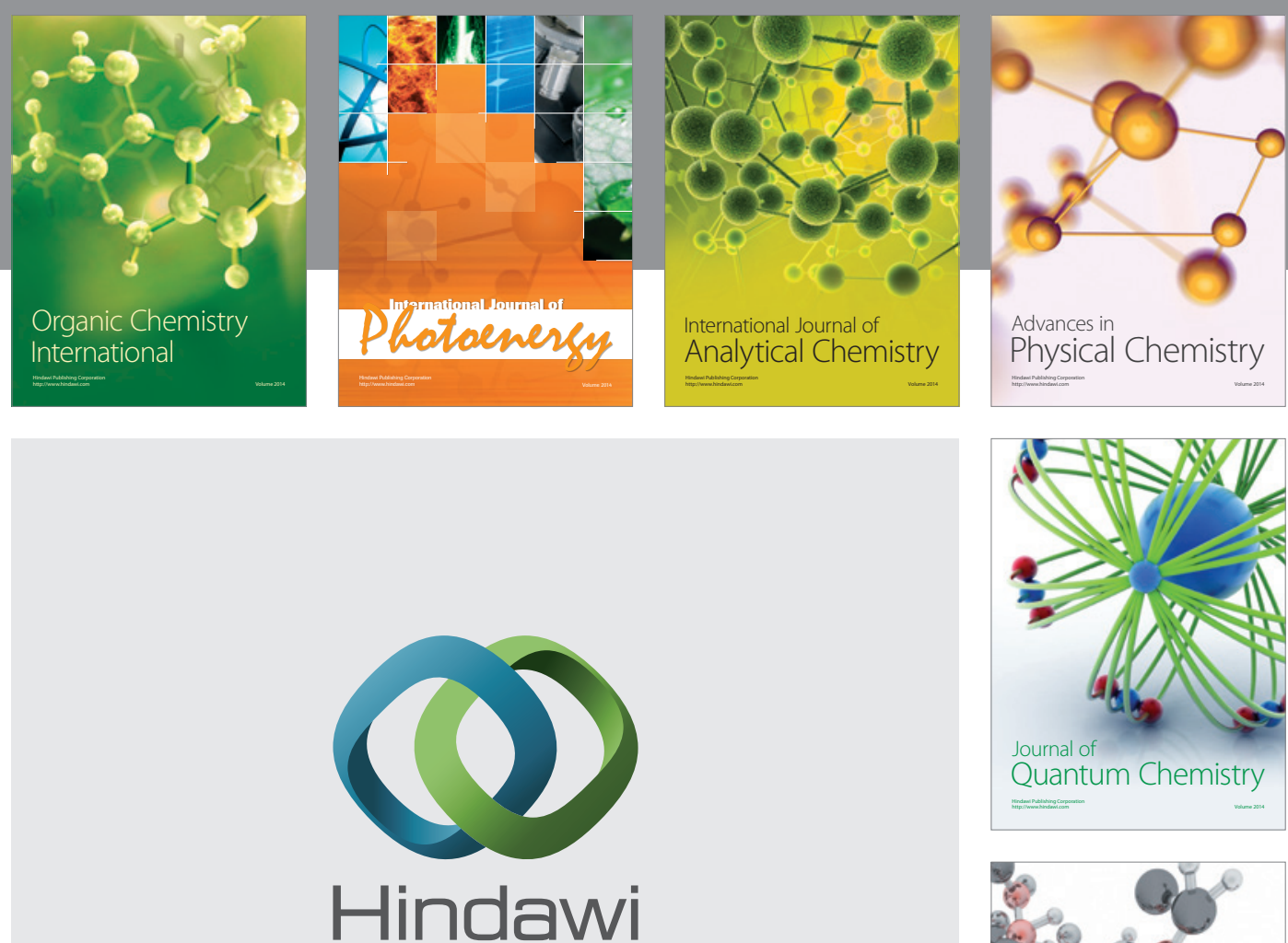

Submit your manuscripts at

http://www.hindawi.com

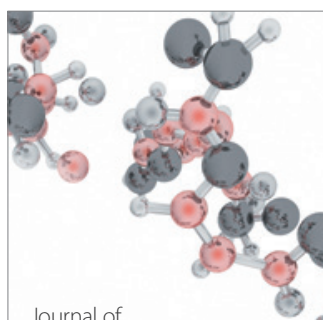

Analytical Methods

in Chemistry

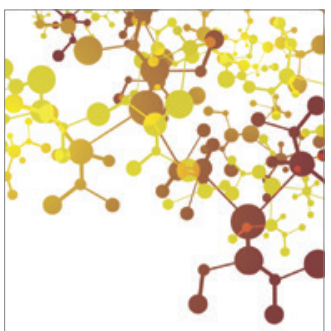

Journal of

Applied Chemistry

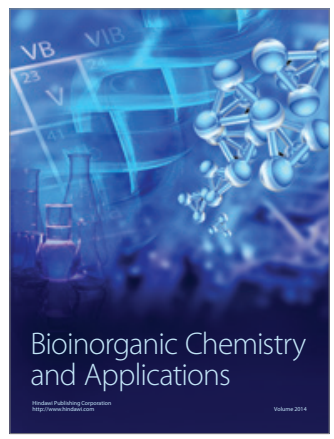

Inorganic Chemistry
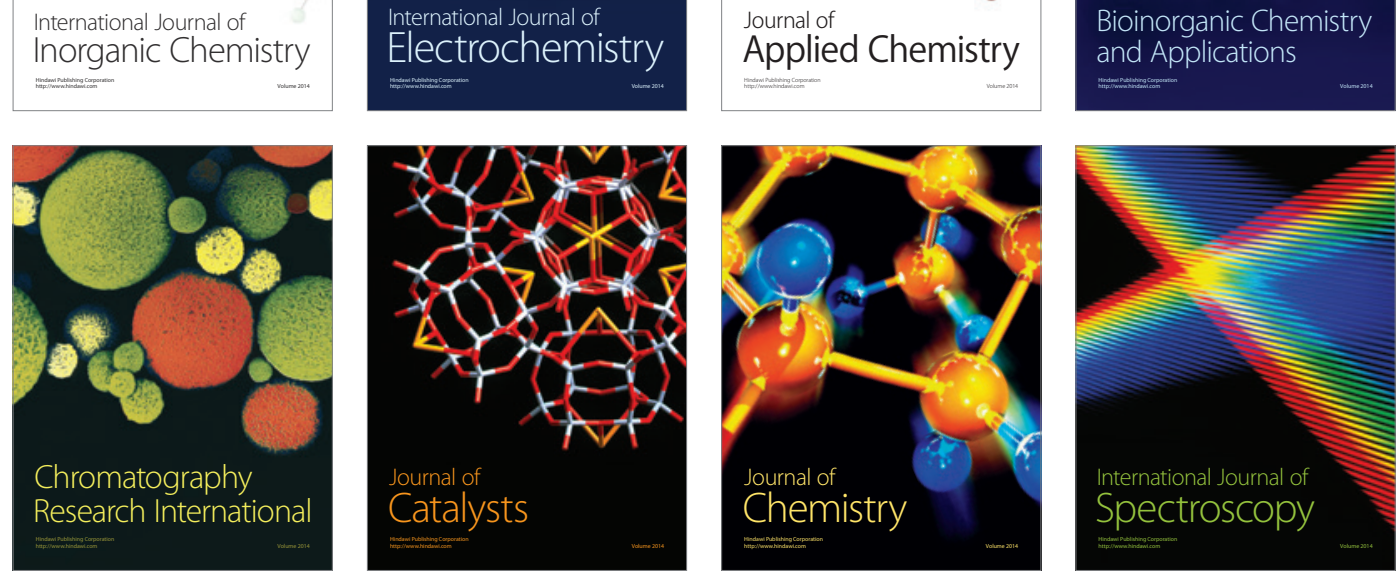